\title{
Avaliação da Eficácia de Procedimento Adotado Para Higienização de Hortaliças Utilizadas em Saladas Cruas Servidas em Um Restaurante Universitário
}

\author{
Verônica Cortez Ginani (I), Eleuza Rodrigues Machado (II,I), Naara \\ Caroline Oliveira de Souza (I), Roberta Figueiredo Resende \\ Riquette (I) \\ (I) UnB - Universidade de Brasília (Campus Darcy Ribeiro - Asa Norte), (II) ANHANGUERA - \\ Faculdade Anhanguera de Brasília (QI 20 Lotes 1-25 - Taguatinga Norte)
}

\section{Resumo}

O consumo de hortaliças cruas tem sido relacionado, cada vez mais, com o aumento de casos de Doenças Transmitidas por Alimentos (DTA). A contaminação por micro-organismos pode ocorrer em diferentes etapas da cadeia produtiva e uma vez presente, a higienização da hortaliça pode ficar comprometida. Neste contexto, esta pesquisa teve como objetivo avaliar a qualidade sanitária de saladas cruas (entradas frias) servidas em um Restaurante Universitário. As saladas foram coletadas, inicialmente, em três dias consecutivos. Os achados foram apresentados à empresa responsável e adotaram-se alterações relativas aos procedimentos de higienização das hortaliças. Sequencialmente, para avaliação da eficácia dos novos procedimentos, após dois meses, foram coletadas novas amostras em seis dias distintos, durante duas semanas. No total, foram analisadas 15 amostras de saladas, em duplicata, conforme protocolos utilizados pela APHA para identificação do Número mais Provável de Coliformes Totais e Termotolerantes. As formas evolutivas de enteroparasitos (cistos, ovos e larvas de helmintos) foram processadas usando o método de Sedimentação Espontânea, e as leituras feitas em Microscópio Óptico (objetivas de 20 e 40x). Em cada momento, foi elaborado fluxograma das etapas in loco, para comparação posterior. De acordo com os resultados obtidos para Coliformes Termotolerantes e parasitas, nas amostras iniciais, $66,7 \%$ foram

\footnotetext{
Referência:

Verônica Cortez Ginani, Eleuza Rodrigues Machado, Naara Caroline Oliveira de Souza, Roberta Figueiredo Resende Riquette. Avaliação da Eficácia de Procedimento Adotado Para Higienização de Hortaliças Utilizadas em Saladas Cruas Servidas em Um Restaurante Universitário. In: Anais do 12을 Congresso Latinoamericano de Microbiologia e Higiene de Alimentos - MICROAL 2014 [= Blucher Food Science Proceedings, num.1, vol.1]. São Paulo: Editora Blucher, 2014. 
classificadas como em condições sanitárias insatisfatórias de acordo com a legislação. Os resultados foram alterados no segundo momento, sendo apenas $7,7 \%$ das amostras condenadas. A avaliação de Coliformes Totais foi considerada elevada (> 1,1 x $103 \mathrm{NMP} / \mathrm{g}$ ) em 100\% das amostras, nos dois momentos e as formas evolutivas de parasitas encontradas foram: ovo de ancilostomídeos (8,3\%), cisto de E. histolytica/dispar (16,7\%), cistos de Entamoeba sp (espécies não identificadas - 33,3\%) e presença de fungos $(75,0 \%)$. Com as análises dos fluxogramas, observou-se maior critério na utilização de saneantes no segundo momento. Os resultados mostram a importância de avaliação contínua dos procedimentos de higienização adotados em serviços de alimentação. Ressaltam-se ainda a necessidade de padronização de técnicas capazes de retirar os cistos, ovos, larvas de enteroparasitos, fungos e outras sujidades comuns em hortaliças.

Palavras-Chave: enteroparasitos, micro-organismo, qualidade sanitária, restaurantes, saladas

Agência de Fomento: Universidade de Brasília 